\title{
Short Communication: Stimulatory effect of Curcuma mangga on immune response against Staphylococcus aureus
}

\author{
YUANDANI ${ }^{1,2, \vartheta}$, SONY EKA NUGRAHA ${ }^{3}$, LIA LAILA ${ }^{4}$, SETIA DAME SILABAN ${ }^{1}$, FADHILAH RAMADHANI ${ }^{1}$ \\ ${ }^{1}$ Department of Pharmacology, Faculty of Pharmacy, Universitas Sumatera Utara. Jl. Tri Dharma, Padang Bulan, Medan 20155, North Sumatra, \\ Indonesia. Tel./fax.: +62-61-8223558, •email: yuandani@usu.ac.id; yuan_dani@yahoo.com \\ ${ }^{2}$ Centre of Excellence for Chitosan and Advanced Materials. Universitas Sumatera Utara. Jl. Tri Dharma, Padang Bulan, Medan 20155, North Sumatra, \\ Indonesia \\ ${ }^{3}$ Department of Pharmaceutical Biology, Faculty of Pharmacy, Universitas Sumatera Utara. Jl. Tri Dharma, Padang Bulan, Medan 20155, North Sumatra, \\ Indonesia \\ ${ }^{4}$ Department of Pharmaceutical Technology, Faculty of Pharmacy, Universitas Sumatera Utara. J1. Tri Dharma, Padang Bulan, Medan 20155, North \\ Sumatra, Indonesia
}

Manuscript received: 20 June 2020. Revision accepted: 7 September 2020.

\begin{abstract}
Yuandani, Nugraha SE, Laila L, Silaban SD, Ramadhani F. 2020. Short Communication: Stimulatory effect of Curcuma mangga on immune response against Staphylococcus aureus. Nusantara Bioscience 12: 109-113. Recently, the ethanol extract of Curcuma mangga Val. rhizomes were found to have immunomodulatory activity by enhancing phagocytic ability. This study was carried out to evaluate the effect of $C$. mangga rhizomes on antibody titer and delayed-type hypersensitivity response in normal and doxorubicin-induced rats against Staphylococcus aureus. The extract was administered orally at doses of 100, 200, and $400 \mathrm{mg} / \mathrm{kg}$ body weight (bw) to rats for 72 hours prior to sensitization of Staphylococcus aureus, then continued for 14 days. Doxorubicin $(4.67 \mathrm{mg} / \mathrm{kg}$ bw) was administered on days 8 and 11 to suppress the immune system. The antibody titer of normal and immune-suppressed rats after the treatment with $C$. mangga ethanolic extract was significantly higher than the rats with negative control $(\mathrm{P}<0.05)$. Ethanol extract of $C$. mangga also demonstrated stimulation on delayed-type hypersensitivity response which was indicated by the increase of paw volume. The extract at dose of $400 \mathrm{mg} / \mathrm{kg}$ bw showed higher immunostimulatory activity than Levamisole as a positive control. The results indicated that the ethanol extract of $C$. mangga shows immunostimulatory activity, confirming its potential to be developed as a therapeutic agent.
\end{abstract}

Keywords: Curcuma mangga, Staphylococcus aureus, doxorubicin, antibody titer, delayed-type hypersensitivity response

\section{INTRODUCTION}

Human body has developed a remarkably sophisticated defense system consisting of various organs, tissues, and cells that are distributed throughout most of the body. It is used to repeal invasive pathogens including bacteria, viruses, fungi, and parasites such as protozoa and worms that may harm the body. Human immune response is divided into two main categories such as innate immunity and adaptive immunity (Beutler 2004). Innate immune system is our first line of defense while adaptive immune system acts as the second line of defense and provides protection against re-exposure to the same pathogen. Innate immunity is the most universal and acts the most rapidly, mostly depends on polymorphonuclear neutrophils (PMNs), peripheral blood mononuclear, and macrophage cells, whereas adaptive immune response depends upon lymphocytes, which provide long term immunity (Beutler 2004; Saroj et al. 2012). In response to invasive bacterial infection, phagocytes (such as macrophages) perform a number of phagocytic activities, including migration to the site of inflammation and adherence towards vascular endothelial cells. Then these pathogens are killed once they are recognized by the intracellular destruction (Beutler 2004; Kobayashi et al. 2005). Macrophages also initiate the adaptive immune response to most pathogens by presenting antigen to $\mathrm{CD} 4+\mathrm{T}$ cells via class II major histocompatibility complex (MHC) antigen (Chapel et al. 2006).

Normally the immune system recognizes the body own tissues as 'self' without any reaction against them, but reacts only against foreign antigens. However, immune responses are not always beneficial (Descotes 2011). Defects or malfunctions in immune system can cause disorders either to the innate or adaptive immune response which can lead to illness or disease. Such disorders are generally caused by one of the following three cases such as inappropriate reaction to self-antigen (known as autoimmunity), overactive immune response (known as hypersensitivity reaction), or ineffective immune response (known as immunodeficiency) (Zhernakova et al. 2009; Warrington et al. 2011). Thus, immunomodulators are required to treat those disorders.

Immunomodulators are substances used to modulate the components of immune system, including both innate and adaptive arms of immune response, and keep them in a highly prepared state for any threat they may encounter (Patil et al. 2012). Immunomodulator substance is necessary for the treatment of various diseases or to encounter adverse events of some drugs, such as doxorubicin. Doxorubicin inhibits cell division, hence its 
usage in chemotherapeutic treatment of malignant diseases. However, this drug suppresses immune response (Carvalho et al. 2009). Thus, immune-enhancing agent is required to protect the body against infectious agents. Staphylococcus aureus is a gram positive bacteria that can cause some health problems, such as pneumonia, skin infections, and endocarditis Myles et al. 2012).

There are several chemical immunomodulators available in the market. Unfortunately, some of these commercial drugs have side effects. Therefore, safer drugs are required as alternatives. Natural products can become one of the important sources of new alternative and safe immunomodulatory agents (Elgert 2009). Since ancient times, focus on the use of traditional herbs as alternative treatment has been revived all over the world. Nowadays, people also use some of the crude extracts of certain herbs as daily food supplements (Yeap et al. 2007). Thus, the research on natural products continues to explore a variety of lead structures, which may be used as templates for the development of new drugs by the pharmaceutical industry (Lahlou 2013). Along this path, several plant extracts and their isolates have been reported for their immunomodulatory activity. Previous studies reported immunomodulatory effects from Camellia sinensis, Coriolus versicolor, Phyllanthus niruri, Rosa canina, Chromolaena odorata, Curcuma domestica, Curcuma xanthorrhiza, Garcinia mangostana, Piper nigrum, Labisia pumila, and Zingiber cassumunar (Yeap et al. 2007; Chairul et al. 2009; Jantan et al. 2011; Hidanah et al. 2018; Rahayu et al. 2018; Pramudya et al. 2019).

Curcuma mangga Val rhizomes are one of the medicinal plants that has been used widely as folk medicine. C. mangga belongs to Zingiberaceae (Hong 2016). It is an origin of Indo-Malaysia and distributed widely in various countries, such as China, Taiwan, Thailand, and Australia. In Malaysia, it is known as temu pauh, while in Thailand it is called kha min khao. $C$. mangga rhizome has a specific smell like mangoes. This plant has been used as the empirical treatment of various diseases like cancer, fever, and stomach disorders (Malek et al. 2011). The plant has been found to have anti-cancer, anti-inflammatory, and antifungal activities (Jantan et al. 2003; Ruangsang et al. 2010; Karsono et al. 2014). The biological activities of $C$. mangga might be due to the presence of various active compounds which include flavonoids, terpenoids and steroids (Abas et al. 2005; Malek et al. 2011). Previous studies have also reported the pharmacological activities of $C$. manga as immunomodulating agent by enhancing phagocytosis ability in mice (Yuandani et al. 2019). In the present study, the activity of $C$. mangga rhizome to stimulate the immune response against $S$. aureus both in normal rats and doxorubicin-induced rats was investigated.

\section{MATERIALS AND METHODS}

\section{Reagents and instruments}

Various chemicals were used in this study, such as phosphate buffer saline (PBS) and natrium carboxymethylcellulose (Na CMC) purchased from Sigma (USA), levamisole (Soho, Indonesia), and Ethanol (SmartLab, Indonesia). Some instruments used in this study were plethysmometer (Ugo Basile, Italy) and Rotary evaporator (Heidolph, Germany).

\section{Plant materials}

Rhizomes of $C$. mangga were collected from North Sumatra, Indonesia. The plant sample was identified and authenticated by a biologist in Herbarium Medanense, Universitas Sumatera Utara, Indonesia (4679/MEDA/2019).

\section{Extraction procedure}

Curcuma mangga rhizomes were dried and ground, then it was macerated by ethanol $96 \%$ with a ratio of $1: 10$. Thereafter, the filtrate was combined and the solvent was evaporated by using a rotary evaporator to get ethanol extract of $C$. mangga.

\section{Antigen preparation}

Staphylococcus aureus was cultivated in nutrient broth agar (NBA) and incubated for $24 \mathrm{~h} .1 \mathrm{ml}$ Aliquot was added with $9 \mathrm{~mL} \mathrm{NBA}$. The concentration of the cell was calculated by using spectrophotometry method to obtain 1 $\mathrm{x} 10^{8}$ cells $/ \mathrm{mL}$ concentration. Next, the mixture was centrifuged at $10,000 \mathrm{rpm}$ for 10 minutes at $25^{\circ} \mathrm{C}$. The supernatant was discarded. Then, the cells were resuspended with $1 \mathrm{ml}$ of PBS.

\section{Delayed-Type Hypersensitivity (DTH) response}

Delayed-type hypersensitivity (DTH) response activity of the extract was investigated by the increase or decrease in paw volume based on the modified method by Ahirwal et al. (2015). Wistar rats were divided into several groups such as normal group and doxorubicin-induced group. Each group was further divided into negative control group (administered with $\mathrm{Na}$ CMC $0.5 \%$ ), positive control (orally administered with levamisole $25 \mathrm{mg} / \mathrm{kg} \mathrm{BB}$ ), and treatment group (orally administered with $C$. mangga extract at various doses of 100, 200, and $400 \mathrm{mg} / \mathrm{kg}$ bw). Curcuma mangga extract or $\mathrm{Na} \mathrm{CMC} 0.5 \%$ or levamisole were administered to the animals for 72 hours prior to sensitization of $S$. aureus $\left(1 \times 10^{8}\right.$ cells $\left./ \mathrm{mL}\right)$ by intraperitoneal injection and then continued until 14 days. Doxorubicin $(4.67 \mathrm{mg} / \mathrm{kg} \mathrm{bw})$ was used to suppress the immune response. Doxorubicin was administered on days 8 and 11 in immune-suppressed groups. On day 14, the rat's paw volume was measured by using plestimometer. Then, all of the test animals were injected with the same amount of $S$. aureus in the hind footpad. After 24 hours, the paw volume was measured again. This study was approved by the Animal Research Ethics Committees of Universitas Sumatera Utara (approval number 0260/KEPH-FMIPA/20I9).

\section{Antibody titer assay}

The effect of $C$. mangga on antibody titer was investigated by using agglutination method (Ahirwal et al. 2015). On day 14, before the animal was injected by $S$. aureus to evaluate the DTH response, blood samples were collected from each animal through the vein tail. The serum 
was obtained by centrifuging the blood samples. The titer was determined by titrating the $S$. aureus antigen-diluted serum. Agglutination was observed visually. Mean log of antibody titer $[2(\log$ titer $)+1]$ was determined to compare the results.

\section{Statistical analysis}

The data were presented as mean \pm SD and analyzed with SPSS software using a one-way analysis of variance (ANOVA) and followed by post hoc Tukey.

\section{RESULTS AND DISCUSSION}

\section{Delayed-Type Hypersensitivity (DTH) response}

Microorganisms attack in various different forms, thus various immune responses are required to encounter each type of infection (Kobayashi et al. 2005). This function is mediated by various cells and molecules which are able to recognize and destroy various pathogens and undesirable materials. Cell-mediated defenses and humoral-mediated defenses are different systems but their mechanisms are overlapping and these help to fight invading organisms (Saroj et al. 2012). The cellular response to S. aureus was evaluated by determining delayed-type hypersensitivity (DTH) response. Delayed-type hypersensitivity is a subtype of Type IV Hypersensitivity facilitated by CD4+ T-cells effector to the environmental or microbial antigens. This response occurs after the re-exposure to the same environmental or microbial antigens. Antigen Processing Cells (APCs) engulf in the microbial or environmental antigens, then degrade them and present their peptides fragment incorporation with MHC class II antigen on the APCs surface. The interactions T cell receptor (TCR) on T helper surface initiate the differentiation of $\mathrm{T}$ helper. Th1 subset releases interferon $\gamma$ that activates macrophage. Subsequently, the activation of macrophage induces inflammation of local tissue (Chapel et al. 2006). In this study, the extract of $C$. mangga rhizome was able to enhance paw volume of normal and doxorubicin-induced rats after the injection of $S$. aureus (Table 1). The increase in paw volume indicated stimulation on DTH response. The stimulatory activity of $C$. mangga extract on cellular response was dependent on the dose given. The extract at dose of $400 \mathrm{mg} / \mathrm{kg}$ bw displayed higher stimulation than Levamisole as a positive control in normal group. The result was in agreement with a previous study that reported the ability of nano curcumin to enhance the DTH response (Afolayan et al. 2018).

\section{Antibody titer}

The humoral component of acquired immunity mainly is the antibody produced by $\mathrm{B}$ cells. After the recognition of a specific antigen, B cells proliferate and differentiate into plasma cells; releasing a large number of receptor molecules in soluble form that can be secreted. This is known as antibodies (Roitt et al. 2001). They can directly recognize protein, polysaccharide, glycolipid, or nucleic acid antigens in their natural state (undigested). Some activated $\mathrm{B}$ cells form memory cells, which can remain silent for a long time but can be activated immediately after the re-exposure to antigen.

Table 1. The effect of Curcuma mangga extracts on delayed-type hypersensitivity $(\mathrm{DTH})$ response (mean \pm SEM)

\begin{tabular}{cll}
\hline Groups & \multicolumn{1}{c}{ Samples } & $\begin{array}{c}\text { Paw volume } \\
(\Delta \mathbf{V})\end{array}$ \\
\hline Normal rats & CMC Na $0.5 \%$ & $0.41 \pm 0.13$ \\
& Levamisol $25 \mathrm{mg} / \mathrm{kg} \mathrm{bw}$ & $1.63 \pm 0.09^{*}$ \\
& C. mangga extract $100 \mathrm{mg} / \mathrm{kg} \mathrm{bw}$ & $0.88 \pm 0.03^{*}$ \\
& C. mangga extract $200 \mathrm{mg} / \mathrm{kg} \mathrm{bw}$ & $1.41 \pm 0.04^{*}$ \\
& C. mangga extract $400 \mathrm{mg} / \mathrm{kg} \mathrm{bw}$ & $2.18 \pm 0.20^{*}$ \\
& & \\
Doxorubicin & CMC Na $0.5 \%$ & $0.25 \pm 0.04$ \\
induced-rats & Levamisole $25 \mathrm{mg} / \mathrm{kg} \mathrm{bw}$ & $1.62 \pm 0.17^{*}$ \\
& C. mangga extract $100 \mathrm{mg} / \mathrm{kg} \mathrm{bw}$ & $0.79 \pm 0.03^{*}$ \\
& C. mangga extract $200 \mathrm{mg} / \mathrm{kg} \mathrm{bw}$ & $1.28 \pm 0.04^{*}$ \\
& C. mangga extract $400 \mathrm{mg} / \mathrm{kg}$ bw & $2.02 \pm 0.25^{*}$ \\
\hline
\end{tabular}

Note: $* \mathrm{P}<0.05$ significant to respective control
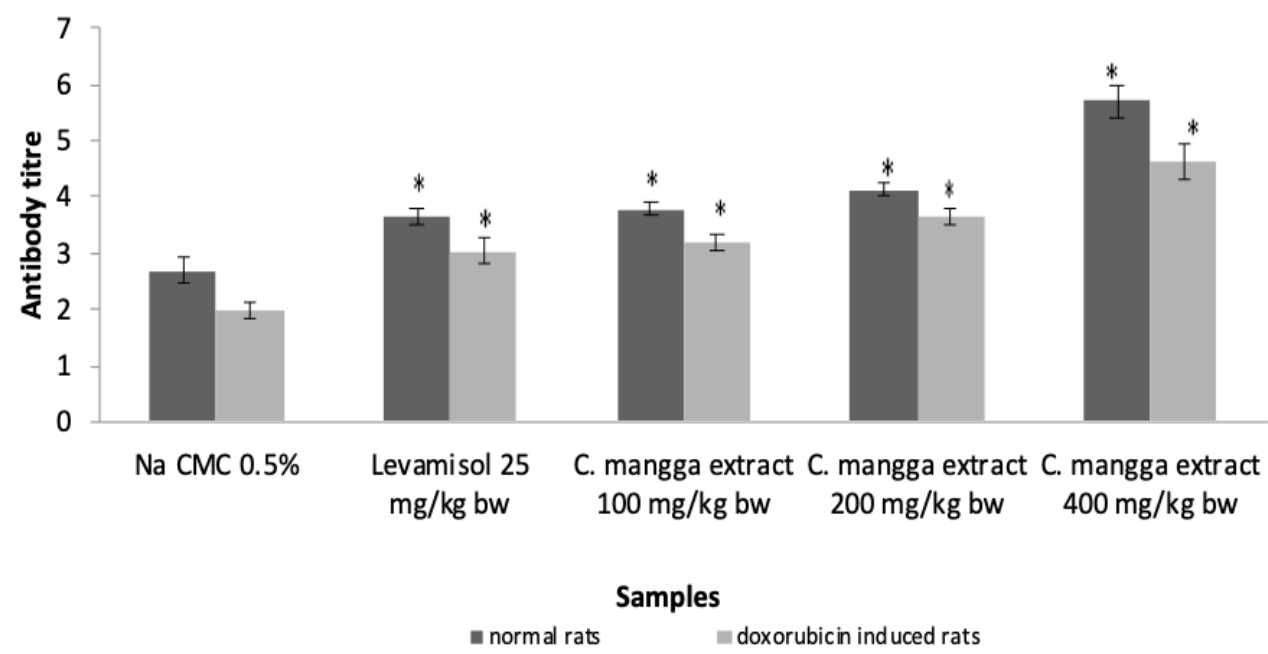

Figure 1. The effect of Curcuma manga ethanolic extract on antibody titer against Staphylococcus aureus; data is mean \pm SEM, $* \mathrm{P}<0.05$ significant with respective control 
Moreover, B cells have another important function which is to present antigen to helper $\mathrm{T}$ cells (Levinson 2012). Adaptive immunity is resulted either by receiving preformed antibody which made it into another host (passive immunity) or from the exposure to environmental or microbial antigens (active immunity) (Saroj et al. 2012). Antibody (Ab), also called immunoglobulins (Ig), can specifically bind to just one antigen by the interaction of an antibody molecule (the Fab portion) against antigen. Other parts of antibody interact with other elements of the immune system such as phagocytes (Chapel et al. 2006). The effect of the extract towards the production of antibody was investigated by agglutination method. Figure 1 shows the effect of $C$. mangga extracts on antibody titer. Curcuma mangga rhizomes extract was able to enhance the antibody titer in the response of invading microorganisms against negative control $(\mathrm{P}<0.05)$. The stimulatory effect was in a dose-dependent manner, indicating by the enhancement of antibody titer value as the dose increased. Surprisingly, $C$. mangga extract exhibited higher stimulation on antibody titer against $S$. aureus than Levamisole as the positive control. The stimulatory activity of $C$. mangga extract was supported by the enhancement of antibody titer value after doxorubicin was induced (Figure 1). This result aligns with the previous study reported immunostimulatory activity of C. mangga to extract on antibody titer against bovine red blood cells (Yuandani et al. 2018).

Various secondary metabolites present in C. mangga rhizome might be responsible for its immunostimulatory activity, such as terpenoids, flavonoids, and glycosides. Previous study reported that flavonoids compounds enhance the immune response (Sharma et al. 1996). Hence, it can be concluded that the ethanol extract of Curcuma mangga rhizomes depicted stimulatory effect on cellular and humoral mediated immunity. The stimulation was observed in both groups with normal rats and doxorubicininduced rats, indicating the ability of $C$. mangga to enhance protection against invading microorganisms in normal and impair immune responses. Therefore, $C$. mangga could be developed into an effective immunomodulatory agent. However, further studies are required to confirm their activities on other mechanisms in immune responses.

\section{ACKNOWLEDGEMENTS}

This study was supported by Ministry of Research and Technology of the Republic of Indonesia, through scheme grant INSINAS with contract number 25/INS2/PPK/E4/2019.

\section{REFERENCES}

Abas F, Lajis NH, Shaari K, Israf DA, Stanslas J, Yusuf UK, Raof SM 2005. Labdane diterpene glucoside from the rhizomes of Curcuma mangga. J Nat Prod 68 (7): 1090-1093. DOI: 10.1021/np0500171.

Afolayan FID, Erinwusi B, Oyeyemib OT. 2018. Immunomodulatory activity of curcumin-entrapped poly d,1-lactic-co-glycolic acid nanoparticles in mice. Integr Med Res 7 (2): 168-175. DOI: 10.1016/j.imr.2018.02.004
Ahirwal L, Singh S, Dubey MK, Bharti V, Mehta A, Shukla S. 2015. In vivo immunomodulatory effects of the methanolic leaf extract of Gymnema sylvestre in swiss albino mice. Arch Biol Sci Belgrade 67: 561-570.

Beutler B. 2004. Innate immunity: On overview. Mol Immunol 40 (12): 845-859. DOI: 10.1016/j.molimm.2003.10.005.

Carvalho C, Santos RX, Cardoso S, Correia S, Oliveira PJ, Santos MS, Moreira PI. 2009. Doxorubicin: The good, the bad and the ugly effect. Curr Med Chem 16 (25): 3267-3285. DOI: 10.2174/092986709788803312.

Chairul P, Praptiwi, Chairul SM. 2009. Phagocytosis effectivity test of phenylbutenoid compounds isolated from bengle (Zingiber cassumunar Roxb.) Rhizome. Biodiversitas 10 (1): 40-43. DOI: 10.13057/biodiv/d100108.

Chapel H, Haeney M, Misbah S, Snowden N. 2006. Clinical Immunology $5^{\text {th }}$ Edition. Blackwell Publishing, Massachusetts.

Descotes J. 2011. Immune Response in Human Pathology: Hypersensitivity and Autoimmunity. In Principles of Immunopharmacology. Springer, Switzerland.

Elgert KD. 2009. Immunology Understanding the Immune System $2^{\text {nd }}$ Edition. A John Wiley \& Sons Inc Publication, Virginia.

Hong GW, Hong SL, Lee GS, Yaacob H, Malek SNA. 2016. Nonaqueous extracts of Curcuma mangga rhizomes induced cell death in human colorectal adenocarcinoma cell line (HT29) via induction of apoptosis and cell cycle arrest at G0/G1 phase. Asian Pac J Trop Med 9 (1): 8-18. DOI: 10.1016/j.apjtm.2015.12.003.

Hidanah S, Sabdoningrum EK, Wahjuni RS, Chusniati S. 2018. Effects of meniran (Phyllanthus niruri L.) administration on leukocyte profile of broiler chickens infected with Mycoplasma gallisepticum. Vet World 11 (6): 834-839. DOI: 10.14202/vetworld.2018.834-839.

Jantan I, Bukhari SNA, Lajis NH, Abas F, Wai LK, Jasamai M. 2011. Effects of diarylpentanoid analogues of curcumin on chemiluminescence and chemotactic activity of phagocytes. J Pharm Pharmacol 64 (3): 404-412. DOI: 10.1111/j.2042-7158.2011.01423.x

Jantan I, Yassin MAM, Chin CB, Chen LL, Sim NL. 2003. Anti-fungal activity of the essential oils of nine Zingiberaceae species. Pharm Biol 41 (5): 392-397. DOI: 10.1076/phbi.41.5.392.15941.

Karsono AH, Tandrasasmita OM, Tjandrawinata RR. 2014. Molecular effects of bioactive fraction of Curcuma mangga (DLBS4847) as a downregulator of $5 \alpha$-reductase activity pathways in prostatic epithelial cells. Cancer Manag Res 6: 267-278. DOI: 10.2147/CMAR.S61111

Kobayashi SD, Voyich JM, Burlak C, DeLeo FR. 2005. Neutrophils in the innate immune response. Arch Immunol Ther Exp (Warsz) 53: 505517.

Lahlou M. 2013. The success of natural products in drug discovery. Pharmacol Pharm 4: 17-31.

Levinson W. 2012. Review of Medical Microbiology and Immunology $12^{\text {th }}$ Edition. The McGraw-Hill Companies, Inc, USA.

Malek SNA, Lee GS, Hong SL, Yaacob H, Wahab NA, Weber JFF, Shah SAA. 2011. Phytochemical and cytotoxic investigations of Curcuma mangga rhizomes. Molecules 16 (6): 4539-4548. DOI: 10.3390/molecules16064539.

Myles IA, Datta SK. 2012. Staphylococcus aureus: An introduction. Semin Immunopathol 34 (2): 181-184. DOI: 10.1007/s00281-0110301-9.

Patil US, Jaydeokar AV, Bandawane DD. 2012. Immunomodulators: A pharmacological review. Int J Pharm Pharm Sci 4: 30-36.

Pramudya M, Wahyuningsih SPA. 2019. Immunomodulatory potential of polysaccharides from Coriolus versicolor against intracellular bacteria Neisseria gonorrhoeae. Vet World 12 (6): 735-739. DOI: 10.14202/vetworld.2019.735-739.

Rahayu RP, Prasetyo RA, Purwanto DA, Kresnoadi U, Iskandar RP, Rubianto M. 2018. The immunomodulatory effect of green tea (Camellia sinensis) leaves extract on immunocompromised Wistar rats infected by Candida albicans. Vet World 11 (6): 765-770. DOI: 10.14202/vetworld.2018.765-770.

Roitt I, Brostoff J, Male D. 2001. Immunology $6^{\text {th }}$ ed. Mosby, London.

Ruangsang P, Tewtrakul S, Reanmongkol W. 2010. Evaluation of the analgesic and anti-inflammatory activities of Curcuma mangga Val and Zijp rhizomes. J Nat Med 64 (1): 36-41. DOI: 10.1007/s11418009-0365-1.

Saroj P, Verma M, Jha KK, Pal M. 2012. An overview on immunomodulation. J Adv Sci Res 3: 7-12. 
Sharma ML, Singh B, Chandan BK, Khajurial A, Kaul A, Bani S, Banerjee SK, Gambhir SS. 1996. Actions of some flavonoids on specific and non-specific immune mechanisms. Phytomedicine 3 (2): 191-195. DOI: 10.1016/S0944-7113(96)80035-3.

Warrington R, Watson W, Kim HL, Antonetti FR. 2011. An introduction to immunology and immunopathology. Allergy Asthma Clin Immunol 7 (Suppl 1): S1. DOI: 10.1186/1710-1492-7-S1-S1.

Yeap SK, Alitheen NB, Ali AM, Omar AR, Raha AR, Suraini AA, Muhajir AH. 2007. Effect of Rhaphidophora korthalsii methanol extracts on human peripheral blood mononuclear cells (PBMC) proliferation and cytolytic activity toward HepG2. J Ethnopharmacol 114 (3): 406-411. DOI: 10.1016/j.jep.2007.08.020.
Yuandani, Yuliasmi S, Satria D, Dongoran RF, Sinaga MS, Marpaung NHA. 2019. Correlation between the phytochemical constituents of Curcuma mangga and its immunomodulatory effect. Rasayan J Chem 12: 1-6.

Yuandani, Yuliasmi S, Satria D. 2018. Analysis of compounds and immunostimulatory properties of Curcuma mangga rhizomes on male mice. Rasayan J Chem 11: 844-849.

Zhernakova A, van Diemen CC, Wijmenga C. 2009. Detecting shared pathogenesis from the shared genetics of immune-related diseases. Nat Rev Genet 10 (1): 43-55. DOI: 10.1038/nrg2489. 